\title{
Annelerin Okul Öncesi Dönem Çocuklarına Kitap Okuma ve Almaya İlişsin Görüşlerinin İncelenmesi*
}

\author{
Analyzing the Views of Mothers on Reading and Buying \\ Books for Their Preschool Children*
}

\author{
Merve TEZEL**, Hande ARSLAN ÇiFTÇi***, Gülden UYANIK****
}

\begin{abstract}
Öz: Bu araştırmanın amacı, okul öncesi dönem çocuklarının annelerinin çocuklarına kitap okuma ve kitap almaya ilişkin görüşlerini derinlemesine incelemektir. Bu araştırma, karma yöntem ile gerçekleştirilmiştir ve okul öncesi dönemde çocuğu olan 292 anneden öz-bildirimlerine dayalı soru formu aracılı̆̆ıly nicel veri ve 9 anne ile de yüz yüze yapılan görüşmeler aracilığıyla nitel veri elde edilmiştir. Elde edilen nicel veriler, frekans ve yüzdeleri hesaplanarak değerlendirilmiştir. Nitel veriler ise betimsel analize tabi tutulmuştur. Araştırmanın sonucunda, annelerin çoğunun kendilerinin ayda bir kitap okuduğu; evinde kendilerine ve eşlerine ait 0-5 arasında kitap olduğu; çocuklarına iki-üç günde bir kitap okuduğu; çocuklarının evde kendine ait kitapların sayısının 0-5 arasında olduğu; çocuklarına yaklaşık üç yaşında kitap okumaya başladığı; çevrelerinde bir halk kütüphanesi olmadığı; çocuklarına kitap alırken, alacakları kitabı çocukları ile birlikte seçtĭgi bulunmuștur. Ayrıca, araştırmaya katılan annelerin çoğu, evlerinde çocuklarının kitaplarını koymak için ayırdıkları özel bir bölüm olduğunu; çocuklarına evde en çok kendilerinin kitap okuduğunu; çocuklarının onlara kitap okumalarından hoşlandığını; kendilerinin de çocuklarına kitap okumaktan hoşlandığını; çocuklarına kitap okuduktan sonra kitaptaki hikâye hakkında bazen sohbet ettiğini ve çocuklarından kitaptaki resimlere bakarak kendisinin bir hikâye oluşturmasını bazen istediğini; çocuklarına ayda bir ya da iki kez kitap aldığını belirtmiştir. Bununla birlikte annelerin çocuklarına kitap alırken, kitabın en çok çocukların gelişim özelliklerine uygun olmasına, kitabın konusuna ve çocuklarının kitabı beğenmesine dikkat ettikleri bulunmuştur.
\end{abstract}

Anahtar Kelimeler: Okul öncesi dönem, kitaplar, anneler, çocuklara kitap okuma, çocuklara kitap alma

\begin{abstract}
The aim of this research is to examine in depth the views of mothers about reading and buying books for their preschool children. This research was conducted through a mixed method. Quantitative data were obtained through question form from 292 mothers of preschool children based on their self-statement and qualitative data were obtained from face-to-face interviews with 9 mothers. The quantitative data obtained were evaluated by calculating frequency and percentage. Qualitative data were subjected to descriptive analysis. Results show that most of the mothers read a book in a month for themselves; have between 0 and 5 books belonging to themselves at home; read to their children every two or three days; have between 0 and 5 books belonging to their children at home; began to read books to their children at about three years old; do not have a public library in their neighborhood; choose books with their children together when buying books. In addition, most of them others stated that they have a special area at home to set aside their children's books; read to their children mostly themselves at home; like to read books to their children and their children also like being read to themselves; sometimes talk with their children about the story after reading; sometimes want from their children to make up a story by looking at the pictures in the book; buy books for their children once or twice a month. It was also found that when buying books for their children, mothers pay attention mostly to whether the book is suitable for children's developmental characteristics, topic of the book and whether their children like the book.
\end{abstract}

Keywords: Preschool period, books, mothers, reading to children, buying books for children

\footnotetext{
* Bu çalışma, 5.Uluslararası Okul Öncesi Eğitim Kongresinde "sözlü bildiri” olarak sunulmuştur.

** Bilim Uzman1, Osmangazi İlkokulu, İstanbul-Türkiye, ORCID: 0000-0001-6816-6144, e-posta: mervetezel@gmail.com

***Araş. Gör. ,İstanbul Medeniyet Üniversitesi, Eğitim Bilimleri Fakültesi, İstanbul-Türkiye, ORCID: 0000-00015061-3882, e-posta: h.arslanciftci@gmail.com

**** Prof. Dr., Marmara Üniversitesi, Atatürk Eğitim Fakültesi, İstanbul-Türkiye, ORCID: 0000-0001-9947-8159, eposta: guyanik@marmara.edu.tr
} 


\section{Giriş}

Okuma, yaşam boyu öğrenmenin anahtarıdır. Bir çocuğun okuma becerilerinin okuldaki, işteki ve genel yaşamındaki başarısı için çok önemli olduğu inkâr edilemez. Ebeveynlerin çocuğuna kitap okuması, çocuğun yaşamı boyunca taşıyacağı okuma başarısı için gerekli olan anlayışı ve becerileri geliştirmek için en önemli etkinliktir. Kitaplara değer veren çocuklar, kendi başlarına okumaya motive olurlar ve muhtemelen hayatlarının geri kalanında da bunu yapmaya devam ederler. Bununla birlikte, çocuklarına düzenli olarak kitap okuyan ebeveynlerin çocuklarıyla daha güçlü bir ilişki kurabilecekleri de göz ardı edilemez bir gerçektir.

Çocuklara yüksek sesle kitap okuma, bir yetişkin veya iyi bir okuyucu ile bir çocuk veya bir grup çocuğun birlikte kitap okumasını kapsayan bir okuma stratejisidir. Kitap okuma, yeni kelime bilgisi, kafiye, resimler hakkında tartışma veya diğer etkileşimli deneyimleri içerebilir veya içermeyebilir (Cunningham ve Zibulsky, 2011). Çocuklar ilkokula başladıkları zaman okumaya karşı yoğun bir ilgi içerisindedirler. Okul öncesi dönemde evde kitapların bulunması, çocukların yetişkinleri okurken gözlemlemesi, yetişkin tarafından çocuğa kitap okunması, okuma ve çocuk edebiyatı hakkında çocukların yetişkinlerle sohbet etme şansı bulması, bu ilgiyi artıran faktörler arasındadır (Sawyer, 2004). Çocuklara kitap okuma, erken okuryazarlık gelişiminin en önemli yönlerinden biri olarak kabul edilmektedir.

Çocuklara yüksek sesle kitap okumanın yararları araştırmalarla kanıtlanmıştır. Çocuklara kitap okuma, erken okuryazarlığa ilişkin çeşitli beceri ve yetenekleri desteklemektedir. Örneğin, birçok araştırmacı, çocuklara kitap okumanın çocukların kelime dağarcığını artırdığını bulmuştur (Beck ve McKeown, 2001; Brabham ve Lynch-Brown, 2002; Sharif, Ozuah, Dinkevich ve Mulvihill, 2003). Çocuklara kitap okuma, çocukları yeni ve daha karmaşık sözcük dağarcığı, söz dizimi, cümle ve metin yapısıyla tanıştırır. Çocuklarla birlikte kitap okuma, çocukların yazı, fonolojik ve fonemik farkındalık, kelime bilgisi, kavrama ve öykü yapısı gibi erken okuma becerilerini geliştirmeleri için otantik bir ortam sağlar (Kennedy ve diğerleri, 2012). Ayrıca, çocuklara kitap okumanın onların dinleme becerilerini artırabileceğine dair kanıtlar da bulunmaktadır (Morrow ve Gambrell, 2002). Çocuklara kitap okumanın sözdizimsel gelişimlerini desteklediği bilinmektedir (Chomsky, 1972). Çocuklara kitap okuma ayrıca, doğru telaffuz, vurgu ve tonlamayı modellemek için de yararlı bir stratejidir. $\mathrm{Bu}$, dil öğreniminin başlangıç aşamalarında özellikle önemlidir (Harris ve Ó Duibhir, 2011). Cunningham ve Zibulsky (2011), yorumlamayı ortaya çıkartarak, geribildirim vererek ve çocuğun dil becerilerine uyum sağlayarak çocuğun aktif katılımının teşvik edildiği bir süreç olan karşılıklı diyaloglarla kitap okumanın sadece sözel dil gelişimi için değil, aynı zamanda kelime tanıma gibi okuryazarlığın diğer kritik yönleri için de yararlı olduğunu ortaya koymuşlardır.

Phillips, Norris ve Anderson (2008) yaptıkları araştırmada, çocuklara kitap okunmasının, çocukların okuryazarlık gelişimini hızlandırmayacağına fakat çocuğun okuma becerileri ve stratejilerinin geliştirilmesine katkı sağlayacağına ve dezavantajlı çocukların da erken okuryazarlık becerisini geliştirmek için etkili bir araç olduğuna dikkat çekmiştir. Strommen ve Mates (2004), altıncı ve dokuzuncu sınıflarda okuyan çocukların ve gençlerin kitap okuma sevgileriyle ilgili yaptıkları araştırmada, evde ebeveynlerin kendilerinin de kitap, gazete, dergi okumalarının ve çocuklarına küçük yaşlarda kitap okumalarının ve kitaptaki karakterler, olaylar üzerine konuşma yapmalarının, çocukları ve gençleri iyi bir okur olma konusunda desteklediği bulunmuştur. Çocuklara kitap okuma uygulamaları ile ilgili yapılan bir araştırmada (Trivette, Simkus, Dunst ve Hamby, 2012) ise, çocuklara aynı kitabı tekrar tekrar okumanın hikâye ile ilgili kelime dağarcığını geliştirdiği ve çocukların hikâyeyi anlamasına olumlu etkisi olduğu bulunmuş ve çocuktan hikâyeyi anlatmasının istenmesinin ve açık uçlu soruların sorulmasının da çocuğun sözel ifadesini geliştirdiğini ortaya konmuştur.

Erken çocukluk döneminden itibaren ebeveynlerin çocuklarına kitap okuma konusunda destek vermeleri önemlidir. Annelerinden veya babalarından okumak için çok destek gören gençlerin s1k s1k okuma ve okumaya yönelik olumlu tutumlara sahip olma ve okumanın hayatta başarmak için önemli olduğunu düşünme olasıl1kları daha yüksektir (Clark ve Hawkins, 2010). İlgili alan yazın incelendiğinde, yetişkinler okuma sürecinde rehber olarak tanımlanmaktadır. Çocuklara uygun ortamlar sağlandığında, çocuklar okumada önemli unsurlar olan hayal gücü, 
yaratıcılık ve eleştirel düşünmeyi kazanabilmektedirler (Majzub ve Abu, 2010). Pozitif ebeveyn davranışları (destekleyici ve 1lımlı olma gibi), hikâye etkileşimi sırasında çocukların odaklanmasını ve heyecan duymasını sağlamaktadır (Kassow, 2006). Çocuklara kitap okuma sadece okuma eylemi ile kalmayıp, yetişkinlerin hikâye okunmasından önce, hikâye okuma sırasında ve sonrasında çocukla birlikte kitapla diyalog içinde olmayı da içermektedir. Bu durum, çocukların dil ve okuryazarlık gelişimini teşvik ederken, kelime hazinesinin artmasına, kavrama becerilerinin gelişmesine ve okuldaki okuma yazma öğretiminde başarısının yükselmesine katkı sağlar. Çocuklar hikâyelerin yapısı, hikâyelerin dili ve okuma davranışının doğası hakkında olumlu bir farkındalık geliştirirler (Saracho ve Spodek, 2010).

Ülkemizde okul öncesi dönem çocuklarına kitap okuma ve kitap alma ile ilgili yapılan çalışmalar incelendiğinde, etkileşimli kitap okumanın beş-altı yaş çocuklarının sosyal durumlara yaklaşımlarına etkisinin incelendiği, anne babaların çocuklarına yönelik kitap ve kitap alımları hakkındaki görüşlerinin araştırıldığı, aile, çevre ve okul öncesi kurumların okul öncesi dönem çocuklarının okuma alışkanlığına etkilerinin değerlendirildiği ve okul öncesi dönem çocuklarının okuma alışkanlıği kazanmasında ailenin rolünün incelendiği çalışmalar olduğu görülmektedir (Ahmetoğlu ve Ceylan, 2011; Çakmak ve Yılmaz, 2009; Çelebi Öncü, 2016; Tezel Şahin ve Tutkun, 2016).

Okul öncesi dönem çocuklarına annelerinin kitap alma ve okumalarına ilişkin araştırma yapılması, çocukların ebeveynlerinin desteği ile ne kadar kitaba ulaştığı ve evde kitaplarla nasıl bir etkileşime girdiği konusunda önemli bir veri sağlayacaktır. Çocuklarla kitap okumanın, okul öncesi dönem çocuğuna yararlarını ortaya koyan araştırmalar düşünüldüğünde, okul öncesinde çocukların kitaplarla daha fazla etkileşime girmelerini sağlayacak destek planlarının oluşturulması için çocuklara evde kitap okunma sıklığının ve niteliğinin belirlenmesi önem taşımaktadır. Bu nedenle bu çalışmanın amacı, ebeveynlerin çocuklarına evde kitap okumalarının sıklı̆̆ını ve niteliğini, tercih edilen çocuk edebiyatı kitaplarını ve ebeveynlerin kendi kitap okuma alışkanlıklarına yönelik görüşlerini incelemektir.

\section{Yöntem}

\section{Araştırma modeli}

$\mathrm{Bu}$ araştırma, nicel ve nitel yöntemlerin birlikte kullanıldı̆̆ bir karma yöntem araştırmasıdır. Nicel sonuçlar, değişkenler arasındaki ilişkilere yönelik genel açıklamalar sağlayabilirler ancak istatistiksel test veya etki büyüklüklerinin aslında ne anlama geldiğine yönelik ayrıntılı bir anlayış sunamazlar. Nitel veri ve sonuçlar, bu anlayışın inşa edilmesine yardımcı olabilirler (Creswell ve Clark, 2015).Bu nedenle bu araştırma iki aşamada tasarlanmıştır. İlk olarak, nicel araştırma desenlerinden tarama modeli kullanılmıştır. Tarama modelleri var olan durumu, var olduğu biçimde ve nesnel bir yaklaşım ile ortaya koyma üzerine temellendirilmektedir (Karasar, 1999).

İkinci olarak, nitel araştırma yöntemlerinden durum çalışması kullanılmıştır. Durum çalışmaları, araştırılan olguyu kendi yaşam çerçevesi içinde inceler ve bir olgu veya olayı derinliğine incelenmesine olanağı verir (Yıldırım ve Şimşek, 2006).

\section{Örneklem grubu}

2016-2017 bahar döneminde İstanbul ili Bayrampaşa, Gaziosmanpaşa, Beyoğlu, Sancaktepe ve Ataşehir ilçelerindeki okul öncesi eğitim kurumlarına devam eden ve tesadüfi olarak seçilen 4-6 yaş arası çocukların gönüllü olarak araştırmaya katılan annelerinden $(n=292)$ oluşmaktadır. Tablo 1 'de annelerin ve çocuklarının demografik bilgileri yer almaktadır. 
Tezel, Arslan Çiftçi ve Uyanık

Tablo 1.

Araştırmaya Katılan Annelerin ve Çocuklarının Demografik Bilgileri

\begin{tabular}{|c|c|c|c|}
\hline Soru & Cevap & $\mathrm{F}$ & $\%$ \\
\hline \multirow[t]{2}{*}{ Okul } & Özel & 21 & 7,2 \\
\hline & Devlet & 271 & 92,8 \\
\hline \multirow[t]{2}{*}{ Okul türü } & Bağımsız anaokulu & 47 & 16,1 \\
\hline & Anasinifi & 245 & 83,9 \\
\hline \multirow[t]{2}{*}{ Çocuğun Cinsiyeti } & $\mathrm{K} 1 \mathrm{z}$ & 155 & 53,1 \\
\hline & Erkek & 137 & 46,9 \\
\hline \multirow{3}{*}{ Çocuğun Yaşı } & 4 & 36 & 12,3 \\
\hline & 5 & 153 & 52,4 \\
\hline & 6 & 103 & 35,3 \\
\hline \multirow{5}{*}{ Anne yaş1 } & 25 ve alt1 & 8 & 2,7 \\
\hline & $26-30$ & 104 & 35,6 \\
\hline & $31-35$ & 100 & 34,3 \\
\hline & $36-40$ & 56 & 19,2 \\
\hline & $41-45$ & 24 & 8,2 \\
\hline \multirow{5}{*}{ Anne Eğitim durumu } & İlkokul & 81 & 27,7 \\
\hline & Ortaokul & 37 & 12,7 \\
\hline & Lise & 105 & 36,0 \\
\hline & Lisans & 62 & 21,2 \\
\hline & Lisansüstü & 7 & 2,4 \\
\hline \multirow{3}{*}{ Annenin Çalışma Durumu } & Evet & 92 & 31,5 \\
\hline & Hayır & 188 & 64,4 \\
\hline & İş arıyorum & 12 & 4,1 \\
\hline \multirow{3}{*}{ Ailenin Gelir durumu } & Üst & 4 & $\overline{1,4}$ \\
\hline & Orta & 253 & 86,6 \\
\hline & Alt & 35 & 12,0 \\
\hline
\end{tabular}

Annelerden alınan cevaplara göre, Tablo 1'de görüldüğü üzere, araştırmaya katılan annelerin çocuklarının \%7,2'si ( $\mathrm{n}=21)$ özel okul öncesi kurumunda; \%92,8'i $(\mathrm{n}=271)$ ise devlet okul öncesi kurumunda eğitim görmektedir. Annelerin çocuklarının \%53,1'i $(\mathrm{n}=155) \mathrm{kız}$, $\% 46,9$ 'u $(n=137)$ erkektir. Annelerin çocuklarının \%12,3'ü $(n=36) 4$ yaş grubunda, \%52,4'ü $(\mathrm{n}=153) 5$ yaş grubunda, \%35,3' $\ddot{\mathrm{u}}(\mathrm{n}=103)$ ise 6 yaş grubunda bulunmaktadır. Araştırmaya katılan annelerin \%2,7'si $(n=8) 25$ ve altı yaş grubunda; \%35,6'sı $(n=104)$ 26-30; \%34,3'ü $(n=100) 31$ 35; \%19,2'si $(\mathrm{n}=56)$ 36-40; \%8,2'si $(\mathrm{n}=24)$ ise 41-45 yaş grubunda bulunmaktadır. Ayrica annelerin, \%27,7'si (n=81) ilkokul; \%12,7 (n=37) ortaokul; \%36's1 (n=105) lise; \%21,2'si ( $\mathrm{n}=62)$ lisans; \%2,4'ü $(\mathrm{n}=7)$ lisansüstü mezunu olduklarını belirtmiştir. Araştırmaya katılan annelerin \%31,5'i (n=92) çalıştığını, \%64,4'ü $(n=188)$ çalışmadığını, \%4,1'i $(n=12)$ ise iş aradığını belirtmiştir. Annelerin \%1,4'ü $(n=4)$ aile gelir durumlarını üst; \%86,6's1 $(n=253)$ orta; \%12'si $(\mathrm{n}=35)$ ise alt olarak belirtmiştir.

Araştırmaya katılan bu annelerden araştırmanın nitel boyutuna katılmada gönüllü olanlar arasından maksimum çeşitlilik örneklemesi yoluyla 9 anne belirlenmiştir. Tablo 2'de görüşmeye katılanbu annelerin ve çocuklarının demografik bilgileri verilmiştir. 
Tablo 2.

Görüşmeye Katılan Annelerin ve Çocuklarının Demografik Bilgileri

\begin{tabular}{|c|c|c|c|c|c|c|c|}
\hline & $\begin{array}{l}\text { Okul } \\
\text { Türü }\end{array}$ & $\begin{array}{l}\text { Çocuğun } \\
\text { Cinsiyeti }\end{array}$ & $\begin{array}{c}\text { Çocuğun } \\
\text { Yaş1 }\end{array}$ & $\begin{array}{l}\text { Anne } \\
\text { Yaş1 }\end{array}$ & $\begin{array}{c}\text { Anne } \\
\text { Eğitim } \\
\text { Durumu }\end{array}$ & $\begin{array}{l}\text { Annenin } \\
\text { Çalışma } \\
\text { Durumu }\end{array}$ & $\begin{array}{c}\text { Ailenin } \\
\text { Gelir } \\
\text { Durumu }\end{array}$ \\
\hline A1 & Devlet & Erkek & 6 & $36-40$ & İlkokul & Çalışmıyor & Orta \\
\hline A2 & Devlet & Erkek & 4 & $31-35$ & Lise & Çalışmıyor & Üst \\
\hline A3 & Devlet & Erkek & 5 & $26-30$ & İlkokul & Çalışmıyor & Orta \\
\hline A4 & Devlet & Erkek & 6 & $31-35$ & Lise & Çalışmıyor & Orta \\
\hline A5 & Devlet & Erkek & 6 & $36-40$ & Lisans & Çalışmıyor & Orta \\
\hline A6 & Devlet & Erkek & 6 & $31-35$ & İlkokul & Çalışmıyor & Orta \\
\hline A7 & Devlet & $\mathrm{K} 1 \mathrm{z}$ & 6 & $26-30$ & İlkokul & Çalışmıyor & Orta \\
\hline A8 & Devlet & K1z & 5 & $41-45$ & Lise & Çalışmıyor & Orta \\
\hline A9 & Devlet & Kiz & 6 & $36-40$ & İlkokul & Çalışmiyor & Alt \\
\hline
\end{tabular}

\section{Veri toplama araçları}

Veri toplama aracı olarak araştırmacılar tarafindan hazırlanan aile bilgi formu, soru formu ve görüşme formu kullanılmıştır.

Aile bilgi formu: Aile bilgi formunda annelerin ve çocuklarının demografik bilgilerine yönelik (çocuğun cinsiyeti, yaşı, eğitim gördüğü okul türü, anne yaş1, eğitim durumu, çalışma durumu ve aile gelir durumu) 7 soru yer almaktadır.

Annelerin çocuklarına kitap okuma ve kitap almaya ilişkin görüşleri soru formu: Araştırmada annelerin öz-bildirimlerine dayalı soru formu aracıllğıyla düşünceleri hakkında nicel veri elde edilmiştir. Araştırmacılar tarafından geliştirilen soru formu, ilgili literatür incelenerek hazırlanmıştır. Daha sonra, hazırlanan taslak form uzman görüşüne sunulmuş (alanda görev yapan üç öğretim elemanı) ve gelen öneriler doğrultusunda düzenlenmiştir.

Soru formunda, annelerin çocuklarına kitap okuma ve kitap alma uygulamalarına ilişkin 24 soru yer almaktadir. Soru formunda hem nicel hem de nitel analize uygun sorulara yer verilmiştir. Açık uçlu sorular ile annelerin görüşlerini daha detaylı olarak yazmalarına firsat sağlamak ve derinlemesine bulgular elde etmek amaçlanmıştır.

Yarı yapılandırılmış görüşme formu: Araştırmanın nitel boyutunda ise annelerin çocuklarına kitap okumaya ve kitap seçmeye ilişkin görüşlerini ve deneyimlerini derinlemesine belirlemek üzere yarı yapılandırılmış görüşmeler yapılmıştır.

Araştırmacılar tarafından geliştirilen görüşme formu; annelerin çocuğuna kitap okumasının amacı ve önemi ( 2 soru), çocuklarına kitap okuma ile ilgili en çok hoşlarına giden nokta (1 soru) çocuklarına kitap okurken dikkat ettikleri noktalar (2 soru), kitap seçimi ve kitap alırken dikkat ettikleri noktalar ( 3 soru) hakkında deneyimlerini ve görüşlerini belirlemeye yönelik toplam 8 açık uçlu sorudan oluşmaktadır.

\section{İşlem}

Annelerle yapılan görüşmeler sınıfta gerçekleştirilmiştir ve yaklaşı 20-25 dakika sürmüştür. Görüşmeler, annelerin izni alınarak ses kayıt cihazı ile kaydedilmiştir. Görüşmelerde yer alan dikkat çekici görüşlere alıntı olarak yer verilmiştir. Görüşmeye katılan anneler A1, A2, A3... şeklinde kodlanmıştır.

Görüşmeden elde edilen veriler iki araştırmacı tarafından analiz edilmiştir. Her iki araştırmacı tarafından yapılan kodlamalara Miles ve Huberman'ın formülü (Güvenirlik= Görüş birliği / Görüş birliği + Görüş ayrılığı) uygulanmıştır. İki kodlayıcı arasındaki uyum \%94 olarak hesaplanmıştır. Güvenirlik hesaplarının \%70 veya üzeri çıkması yeterli görülmektedir. 


\section{Verilerin analizi}

Annelerden soru formları aracılığıla elde edilen nicel verilerin analizinde SPSS 21 programı kullanılmıştır. Elde edilen nicel veriler, frekans ve yüzdeleri hesaplanarak değerlendirilmiş ve tablolar halinde sunulmuştur.

Görüşmelerden elde edilen veriler yazıya aktarıldıktan sonra araştırmacılar tarafından çözümlenmiştir. Veriler, betimsel analize tabi tutulmuştur. Araştırma sorusuna ilişkin kavramsal yapının önceden açık biçimde ortaya konulabilir olması betimsel analiz yönteminin seçilmesini etkileyen temel faktördür (Yıldırım ve Şimşek, 2006).

\section{Bulgular}

Araştırmaya katılan 292 anneden anket aracılı̆̆ ile elde edilen bulgular nicel bulgular, 9 anneden görüşme aracılığı ile elde edilen bulgular ise nitel bulgular başlıkları altında sunulmuştur.

\section{Nicel bulgular}

$\mathrm{Bu}$ bölümde araştırmaya katılan annelerin çocuklarına kitap okuma ve kitap alma uygulamalarının incelenmesi amaciyla anket formunda yer alan bilgilerden elde edilen bulgulara yer verilmiştir. Elde edilen bulgular tablolarla sunularak yorumlanmıştır.

Tablo 3.

Araştırmaya Katılan Annelerin Kendilerinin Kitap Okuma Alışkanlıklarını Gösteren Frekans ve Yüzde Değerleri

\begin{tabular}{llcc}
\hline \multicolumn{1}{c}{ Soru } & \multicolumn{1}{c}{ Cevap } & F & $\%$ \\
\hline Kendiniz kitap okur musunuz? & Evet & 197 & 67,5 \\
& Hayır & 95 & 32,5 \\
\hline & Haftada bir kitap & 21 & 7,2 \\
& 2-3 haftada bir kitap & 35 & 12 \\
Ne sıklıkta kendiniz kitap okursunuz? & Ayda bir kitap & 65 & 22,3 \\
& İki-üç ayda bir kitap & 50 & 17,1 \\
& Altı ayda bir kitap & 26 & 8,6 \\
& Kitap okumuyorum & 95 & 32,5 \\
\hline Evde sizin ve eşinizin kaç tane kitabı var? & $0-5$ & 96 & 32,9 \\
& $6-10$ & 51 & 17,5 \\
& $11-15$ & 24 & 8,2 \\
& $16-20$ & 24 & 8,2 \\
& 20 'den fazla & 88 & 30,1 \\
& Cevap yok & 9 & 3,1 \\
\hline
\end{tabular}

Tablo 3'te görüldüğü üzere, araştırmaya katılan annelerin \% 67,5'i $(\mathrm{n}=197)$ kendileri kitap okumakta, \%32,5'i $(n=95)$ ise kitap okumamaktadır. Kendileri kitap okumayan annelerin $(n=95)$ kitap okumama nedenleri incelendiğinde; küçük çocukları olduğu, zaman bulamadıkları, kitap okuma alışkanlıklarının olmadıkları, kitap okumayı sevmedikleri ve sıkıldıkları için kitap okumadıklarını belirttikleri görülmüştür. Annelerin \%7,2'si $(n=21)$ kendilerinin haftada bir kitap, $\% 12$ 'si (n=35) 2-3 haftada bir kitap, \%22,3'ü (n=65) ayda bir kitap, \%17,1'i $(\mathrm{n}=50)$ iki-üç ayda bir kitap, \%8,6'sı $(\mathrm{n}=26)$ ise altı ayda bir kitap okuduklarını belirtmiştir. Araştırmaya katılan annelerin ve eșlerinin kendilerine yönelik evde \%32,9'unun $(\mathrm{n}=96)$ 0-5 adet arasında kitab1 olduğu, \%17,5'inin (n=51) 6-10 adet arasında kitabı olduğu, \%8,2'inin (n=24) 11-15 adet arasında kitab1 olduğu, \%8,2'inin (n=24) 16-20 adet arasında kitabı olduğu, \%30,1'inin (n=88) 20 adetten fazla kitabı olduğu, \%3,1'inin ( $\mathrm{n}=9$ ) ise cevap vermediği görülmüştür. 
Tablo 4.

Araştırmaya Katılan Annelerin Çocuklarına Kitap Okumaya İlişkin Görüşlerini Gösteren Frekans ve Yüzde Değerleri

\begin{tabular}{|c|c|c|c|}
\hline Soru & Cevap & $\mathrm{F}$ & $\%$ \\
\hline \multirow[t]{2}{*}{ Çocuğunuza kitap okur musunuz? } & Evet & 250 & 85,6 \\
\hline & Hayır & 42 & 14,4 \\
\hline \multirow{6}{*}{ Çocuğunuza ne sıklıkta kitap okursunuz? } & Her gün & 38 & 13,0 \\
\hline & 2-3 günde bir & 94 & 32,2 \\
\hline & Haftada bir & 67 & 22,9 \\
\hline & İki haftada bir & 30 & 10,3 \\
\hline & Ayda bir & 21 & 7,2 \\
\hline & Kitap okumuyorum & 42 & 14,4 \\
\hline \multirow{7}{*}{$\begin{array}{l}\text { Çocuğunuza kitap okumaya yaklaşık olarak } \\
\text { ne zaman başladınız? }\end{array}$} & 1 yaşından küçükken & 33 & 11,3 \\
\hline & 1 yaşında & 37 & 12,7 \\
\hline & 2 yaşında & 49 & 16,8 \\
\hline & 3 yaşında & 72 & 24,7 \\
\hline & 4 yaşında & 46 & 15,8 \\
\hline & 5 yaşında & 32 & 11,0 \\
\hline & Cevap yok & 23 & 7,9 \\
\hline \multirow[t]{3}{*}{ Evinizin yakınında halk kütüphanesi var mı? } & Evet & 88 & 30,1 \\
\hline & Hayır & 113 & 38,7 \\
\hline & Bilmiyorum & 91 & 31,2 \\
\hline \multirow{3}{*}{$\begin{array}{l}\text { Çocuğunuza kitap almak için halk } \\
\text { kütüphanesine gider misiniz? }\end{array}$} & S1k sik & 1 & 0,3 \\
\hline & Ara sira & 57 & 19,5 \\
\hline & Hiçbir zaman & 234 & 80,1 \\
\hline \multirow{6}{*}{$\begin{array}{l}\text { Çocuğunuzun evde kaç tane kendine ait } \\
\text { kitab1 var? }\end{array}$} & $0-5$ & 81 & 27,7 \\
\hline & $6-10$ & 70 & 24,0 \\
\hline & $11-15$ & 50 & 17,1 \\
\hline & $16-20$ & 26 & 8,9 \\
\hline & 20 'den fazla & 56 & 19,2 \\
\hline & Cevap yok & 9 & 3,1 \\
\hline \multirow{2}{*}{$\begin{array}{l}\text { Evinizde çocuğunuzun kitaplarını koymak } \\
\text { için ayırdığınız kitaplık veya kutu gibi özel } \\
\text { bir bölüm var mı? }\end{array}$} & Evet & 235 & 80,5 \\
\hline & Hayır & 57 & 19,5 \\
\hline
\end{tabular}

Tablo 4'te görüldüğü üzere, araştırmaya katılan annelerin \%85,6's1 $(\mathrm{n}=250)$ çocuğuna kitap okumakta, \%14,4'ü $(\mathrm{n}=42)$ ise kitap okumamaktadır. Cocuğuna kitap okumadığını belirten annelerin $(\mathrm{n}=42)$ kitap okumama nedenleri incelendiğinde; zamanlarının ve kitap okuma alışkanlıklarının olmaması gibi nedenler belirttikleri görülmüştür. Annelerin \%13,0'1nın ( $\mathrm{n}=38)$ her gün, \%32,2'sinin (n=94) 2-3 günde bir, \%22,9'unun ( $n=67)$ haftada bir, \%10,3'ünün $(n=30)$ iki haftada bir, \%7,2'sinin $(\mathrm{n}=21)$ ise ayda bir çocuklarına kitap okudukları görülmüştür. Annelerin \%11,3'ünün $(\mathrm{n}=33)$ çocuğuna kitap okumaya bir yaşından küçükken başladıkları, $\% 12,7$ 'sinin $(\mathrm{n}=37)$ bir yaşında, \%16,8' $\operatorname{sinin}(\mathrm{n}=49)$ iki yaşında, $\% 24,7$ 'sinin $(\mathrm{n}=72)$ üç yaşında, $\% 15,8^{\prime}$ inin $(n=46)$ dört yaşında, \%11,0'ının $(n=32)$ beș yaşında başladığ $1, \% 7,9$ ' unun $(n=23)$ ise cevap vermediği görülmüştür. Annelerin \%30,1'inin $(\mathrm{n}=88)$ evlerinin yakınlarında halk kütüphanesi olduğu, \%38,7'inin (n=113) olmadı̆̆ 1 , \%31,2'sinin $(n=91)$ ise evlerinin yakınlarında halk kütüphanesi olup olmadığını bilmediği bulunmuştur. Ayrıca, annelerin \%80,1'inin ( $\mathrm{n}=234)$ hiçbir zaman halk kütüphanesine gitmediği görülmüştür. Annelerin \%27,7'sinin ( $\mathrm{n}=81)$ çocuklarının evde kendilerine ait 0-5 adet arasında kitabı olduğu, \%24,0'ının (n=70) 6-10 adet, $\% 17,1$ 'inin (n=50) 11-15 adet, \%8,9'unun ( $\mathrm{n}=26)$ 16-20 adet, \%19,2'sinin $(\mathrm{n}=56) 20$ adetten fazla 
kitabı olduğu; \%3,1'inin ( $\mathrm{n}=9$ ) ise cevap vermediği görülmüştür. Annelerin \%80,5'inin ( $\mathrm{n}=235)$ çocuklarının evde kitaplarını koymak için kitaplık veya kutu gibi özel bir bölümü olduğu görülmüştür.

Tablo 5 .

Araştırmaya Katılan Annelerin Çocuklarıyla Kitap Okumaya İlişkin Görüşlerini Gösteren Frekans ve Yüzde Değerleri

\begin{tabular}{llrc}
\multicolumn{1}{c}{ Soru } & \multicolumn{1}{c}{ Cevap } & $\mathrm{F}$ & $\%$ \\
\hline Çocuğunuza evde en çok kim kitap okur? & Annesi & 217 & 74,3 \\
& Babası & 28 & 9,6 \\
& Abisi/ablası & 32 & 11,0 \\
& Diğer yetişkinler & 2 & 7 \\
& Cevap yok & 13 & 4,5 \\
\hline Çocuğunuza kitap okumaktan hoşlanır & Evet & 263 & 90,1 \\
mısınız? & Hayır & 24 & 8,2 \\
& Cevap yok & 5 & 1,7 \\
\hline Çocuğunuz ona kitap okunmasından hoşlanır & Evet & 269 & 92,1 \\
mı? & Hayır & 18 & 6,2 \\
& Cevap yok & 5 & 1,7 \\
\hline Sizin teklif etmediğiniz zamanlarda, & Her zaman & 99 & 33,9 \\
çocuğunuz sizden ona kitap okumanızı ister & Bazen & 153 & 55,8 \\
mi? & Hiçbir zaman & 24 & 8,2 \\
& Cevap yok & 6 & 2,1 \\
\hline Çocuğunuza kitap okuduktan sonra, & Her zaman & 120 & 41,1 \\
çocuğunuzla kitaptaki hikâye hakkında & Bazen & 151 & 51,7 \\
sohbet eder misiniz? & Hiçbir zaman & 18 & 6,2 \\
& Cevap yok & 3 & 1,7 \\
\hline Çocuğunuza kitap okurken, kitaptaki resimler & Evet & 270 & 92,5 \\
hakkında konuşur musunuz? & Hayır & 19 & 6,5 \\
& Cevap yok & 3 & 1,0 \\
\hline Çocuğunuzdan kitaptaki resimlere bakarak & Her zaman & 62 & 21,2 \\
kendisinin bir hikâye oluşturmasını ister & Bazen & 174 & 59,6 \\
misiniz? & Hiçbir zaman & 52 & 17,8 \\
& Cevap yok & 4 & 1,4 \\
\hline
\end{tabular}

Tablo 5'e göre, araştırmaya katılan annelerin \%74,3'inin ( $\mathrm{n}=217)$ evde çocuğa en çok

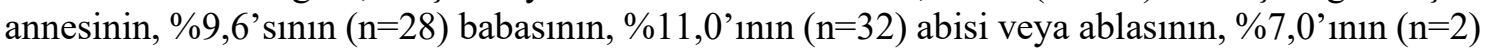
evdeki diğer yetişkinlerin kitap okuduğu, \% 4,5'inin $(n=13)$ cevap vermediği görülmüştür. Annelerin \%90,1'inin ( $\mathrm{n}=263)$ çocuklarına kitap okumaktan hoşlandığı görülmüştür. Annelerin çocuklarına kitap okumayı sevme nedenleri incelendiğinde; çocuklarının merak içinde olmaları, sorular sormaları, bilgilenmeleri, hayal dünyalarının ve kelime hazinelerinin gelişmesinin önemli olduğu, çocuklarının kitap okunurken sakinleşmeleri, mutlu olmaları, iletişimlerinin kuvvetlenmesi, kitap okuma alışkanlığ kazanmaları, uykuya rahat dalmaları ve çocuklarıyla birlikte zaman geçirmeleri gibi nedenler belirtmişlerdir. Annelerin çocuklarının \%92,1'inin $(\mathrm{n}=269)$ kendilerine kitap okunmasından hoşlandığı bulunmuştur. Kendileri teklif etmediği zamanlarda annelerin çocuklarının \%33,9'unun ( $\mathrm{n}=99)$ her zaman, \%55,8'inin $(\mathrm{n}=153)$ bazen kitap okumak istediği; \% $\%$,2'inin (n=24) hiçbir zaman kitap okumak istemediği; \%2,1'inin (n=6) cevap vermediği bulunmuştur. Annelerin \%41,1'inin ( $\mathrm{n}=120)$ her zaman, \%51,7'sinin $(\mathrm{n}=151)$ bazen kitap okuduktan sonra çocuklarıyla kitaptaki hikâye hakkında sohbet ettikleri; \%6,2'sinin $(n=18)$ hiçbir zaman etmediği; \%1,7'sinin $(n=3)$ cevap vermediği görülmüştür. Annelerin $\% 92,5$ 'inin $(\mathrm{n}=270)$ kitap okurken kitaptaki resimler hakkında çocuklarıyla konuştukları, $\% 7,5$ 'inin $(n=22)$ konuşmadıkları görülmüştür. Araştırmaya katılan annelerin \%21,2'sinin $(n=62)$ 
her zaman, \%59,6'sının ( $\mathrm{n}=174)$ bazen çocuklarından kitaptaki resimlere bakarak kendisinin bir hikâye oluşturmasını istedikleri; \%17,8'sinin (n=52) hiçbir zaman istemedikleri ve \%1,4'ünün $(n=4)$ cevap vermediği görülmüştür.

Tablo 6.

Araştırmaya Katılan Annelerin Çocuklarına Kitap Almaya İlişkin Görüşlerini Gösteren Frekans ve Yüzde Değerleri

\begin{tabular}{llrr}
\hline \multicolumn{1}{c}{ Soru } & & \multicolumn{1}{c}{ Cevap } & \multicolumn{1}{c}{$\%$} \\
\hline \multirow{2}{*}{ Çocuğunuza kitap alır mısınız? } & Evet & 271 & 92,8 \\
& Hayır & 21 & 7,2 \\
\hline & Haftada birden fazla & 6 & 2,1 \\
Çocuğunuza ne sıklıkta kitap alırsınız? & Haftada bir & 25 & 8,6 \\
& Ayda bir ya da iki kez & 120 & 41,1 \\
& Birkaç ayda bir & 109 & 37,3 \\
& Cevap yok & 32 & 11 \\
\hline \multirow{3}{*}{ Çocuğunuza kitap alırken, alacağınız } & Anne/baba seçer & 48 & 16,4 \\
kitabı genelde kim seçer? & Çocuğum seçer & 71 & 24,3 \\
& Birlikte seçeriz & 162 & 55,5 \\
& Cevap yok & 11 & 3,8 \\
\hline & Çocukların gelişimine uygun olması & 229 & 29,6 \\
& Kitabın konusu & 188 & 24,3 \\
Çocuğunuza kitap alırken en çok nelere & Ȩocuğumun kitabı beğenmesi & 186 & 24 \\
dikkat edersiniz?* & Kkonomik olması & 48 & 6,2 \\
& Kitabın yazarı/yayınevi & 48 & 6,2 \\
& Resimlerinin kaliteli olması & 30 & 3,8 \\
& Kitabın dış görünüşü & 29 & 3,5 \\
& Cevap yok & 15 & 1,9 \\
\hline
\end{tabular}

*Bu soruya ilişkin katılımcılardan bazıları birden fazla yanıt verdikleri için, verilen yanıtlar ile katılımcı sayısı uyuşmamaktadır.

Tablo 6'da görüldüğ̈̈ üzere, araştırmaya katılan annelerin \%92,8'inin $(n=271)$ çocuklarına kitap aldıkları, \% 7,2'sinin $(\mathrm{n}=21)$ ise almadıkları bulunmuştur. Annelerin \%2,1'sinin $(\mathrm{n}=6)$ haftada birden fazla, \%8,6's1 $(\mathrm{n}=25)$ haftada bir, \%41,1'inin $(\mathrm{n}=120)$ ayda bir ya da iki kez, \%37,3'inin ( $\mathrm{n}=109)$ birkaç ayda bir çocuklarına kitap aldıkları, \%11,0'ının ( $\mathrm{n}=32)$ ise cevap vermediği görülmüştür. Annelerin \%16,4' $\ddot{\mathrm{u}}(\mathrm{n}=48)$ çocuklarına kitap alırken alacakları kitapları anne-babanın seçtiğini, \%24,3'i (n=71) çocuklarının, \%55,5'i $(n=162)$ ise çocuklarıyla birlikte seçtiklerini belirtmiştir. Çocuklarına kitap alırken annelerin \%29,6'sının $(n=229)$ kitabın çocuklarının gelişim özelliklerine uygun olmasına; \%24,3'ünün $(\mathrm{n}=188)$ kitabın konusuna; $\% 24,0$ 'ının ( $\mathrm{n}=186)$ çocuğunun kitabı beğenmesine; \%6,2'sinin $(\mathrm{n}=48)$ ekonomik olmasına; $\% 6,2$ 'sinin $(\mathrm{n}=48)$ kitabı yazarına/yayınevine; \%3,8'inin $(\mathrm{n}=30)$ resimlerinin kaliteli olmasına; $\% 3,5$ 'inin $(\mathrm{n}=29)$ kitabın dış görünüşüne dikkat ettiği bulunmuştur.

\section{Nitel bulgular}

Bu bölümde, 9 anneden görüşmeler aracılığıyla toplanan veriler doğrultusunda elde edilen bulgular ele alınmıştır. Annelerin görüşlerini etkili bir biçimde yansıtmak amacıyla gerekli yerlerde doğrudan alıntılara yer verilmiştir.

Annelere çocuklarına hangi amaçla kitap okudukları sorulduğunda; anneler çocuklarının konuşma becerilerinin gelişmesi, kelime dağarcıklarının gelişmesi, bilgilenmeleri, soru sormaları, hafızalarının gelişmesi, hayal güçlerinin gelişmesi, beraber vakit geçirebilmeleri ve çocuklarının hoşuna gitmesi gibi amaçlarla kitap okuduklarını belirtmişlerdir. Bu konuda bazı annelerin ifadeleri şöyledir: 
Hem kelimeleri daha iyi çözebilmesi konusunda, konuşurken neyi, ne söylediğini anlayabilmesi konusunda kitap okumaya çalışıyorum. A6

Çocuğumun hoşuna gittiği için okuyorum. Sevdiği için. Bilgileniyor. Merak ediyor. Soruyor ne olmuş ne etmiş. Merak ettiği için okuyorum. A7

Annelerin çocuklarına kitap okumada en çok hoşuna giden şeyler sorulduğunda; annelerin çocuklarının soru sormaları, sorulan sorulara cevap verebilmeleri, dinlemeleri, merak etmeleri, hayal kurmaları, bir şeyler öğrenmeleri, kitap okunmasını sevmeleri ve çocukların kitap okunmasını istemeleri, çocuklarıyla beraber vakit geçirmeleri, çocuklarının kitap sayesinde daha iyi cümle kurmaları, kendilerinin de kitaplardan bir şeyler öğrenebildikleri gibi cevaplar verdikleri görülmüştür. Bu konuda bazı annelerin ifadeleri şöyledir:

Masal kitaplarından sonra daha çok hayal kurmaya başladı ve kendi cümleleri masal kitaplarına göre olmaya başladı. Daha önce devrik cümle kurarken şimdi daha anlamlı cümleler kuruyor. Al

İlgisini çektiği zamanlarda merakını gidermek için sorular sorması. Soru cevabı getiriyor, soru cevabi getiriyor. A4

Annelere çocuklarına kitap okumalarının önemli olup olmadığı sorulduğunda; araştırmaya katılan annelerin hepsi kitap okumanın önemli olduğunu belirtmiştir. Annelere çocuklarına kitap okumalarının neden önemli olduğu sorulduğunda ise; anneler, kitap okumanın çocukların konuşma, tartışma, soru sorma becerilerini geliştirdiğini; kitap okuma sayesinde çocukların kavramları öğrendiklerini, hayal güçlerinin zenginleştiğini, çocukların bilgisinin arttığı belirtmişlerdir. Bu konuda bazı annelerin ifadeleri şöyledir:

Bence çok önemli. Çünkü ben okumak istedim ailem beni okutmadl. Ben önceden çok kitap okurdum, evlendiğim zaman okuyamadım. Ben kendim herhalde zaman ayıramıyorum, o yüzden benim içimde kalmış olan bir şeyi çocuklarıma yaşatmayı seviyorum. A3

Artı bir süre sonra kendi o kitabı getiriyor bana, anne bunu bana okuyabilir misin diye soruyor; bu da bence güzel bir şey gelişimi konusunda. Çocuğun bilgisini geliştiriyor. Bazı kelimeler çıkıyor, o kelimenin ne olduğunu biliyor. Başka bir yerde de o cümleyi görse benim okuduğum hikâyeden onun ne demek istediğini anliyor; anlamını anliyor yani. Sohbetlere katılabiliyor, daha konuşkan oluyor; okulda da gördüm. A6

Mesela, çocuk kelime haznesini çok geliştiriyor. Hayal gücü çok gelişiyor. Benim oğlumda konuşma bozukluğu, kekemelik var. Ben bunun için de çok kitap okuyorum. Okuduğuтu опи tekrar etmesini istiyorum ve daha seri konuştuğunu görebiliyorum. Daha düzgün cümleler kurduğunu görebiliyorum çocuğumun. Anne baba olarak da bunu yapmamı lazım bence. A9

Annelere çocuklarına kitap okurken, kitaptaki resimler hakkında konuşup konuşmadıkları ve konuşuyorlarsa nasıl konuştukları sorulduğunda, annelerin hepsi resimler hakkında konuştuklarını ve resimlere bakarak soru cevap şeklinde konuştuklarını, resimleri çocuklarına anlattırdıklarını, resimlere bakarak çocuklarının hikâye oluşturduklarını belirtmişlerdir. Bu konuda bazı annelerin ifadeleri şu şekildedir:

Konuşuyoruz, hatta uzun uzun konuşuyoruz. Mesela resimde ilginç bir şey gördüğü zaman, 'Anne niye böyle yapmış, niye böyle yapmamış da öyle yapmış?' gibi sorular soruyor, onları açılamayı seviyorum. A4 
Ben okuduktan sonra tekrar kendi kitabı alıp resimleri bana anlattyor. Bazen direkt kendi kitabı alıyor, 'ben sana bunu okuyayım anne' diyor. Resimlere bakarak bana okuyor. Resimlere bakarak ne dediğini kendi üretiyor. A6

Şöyle; o soruyor, ben söylüyorum. Bu niye burada durmuş, bu niye böyle diye işte soruyor. Durduruyoruz okumayl, resimler hakkında bir şeyler soruyor, sonra devam ediyoruz. A8

Annelere kitap bittikten sonra okudukları hikâye hakkında çocuklarıyla sohbet edip etmedikleri ve ediyorlarsa nasıl ettikleri sorulduğunda; araştırmaya katılan annelerden sadece bir tanesi etmediğini belirtmiş; diğer annelerin ise kitabı anlattırarak ya da sorular sorarak sohbet ettikleri bulunmuştur. Bazı kitapların arkasında yer alan soruların da soru sormak için kullanıldığ bir anne tarafından belirtilmiştir. Bu konuda bazı annelerin ifadeleri şöyledir:

Daha çok sorular sorarız. Mesela diyelim bir hikâye okuduk; 'Ali ne ile mutluymuş?' gibi sorular sorarim. Al

Evet, ne anladın diye ona soruyorum. O da bana özetle bunu yapmamı gerekiyormuş diye cevap veriyor. Daha çok kitabı anlattırlyorum. Soru cevap yapmiyorum ona daha çok, vaktimiz kalmiyor. A6

Bana anlatmasını istiyorum. Çünkü anlatmadığ zaman biliyorum ki anlamıyor. Bir çocuk ona okuduğumu bana anlatamadı̆̆ zaman, benim ona okuduğumu anlamıyor demektir. Anlamadiğını düşünürüm. Anladığg zaman direkt bu okuduğum hikâyeyi başkalarına da anlatıyor oğlum. A9

Araştırmaya katılan annelere çocuklarına kitap alırken nelere dikkat ettikleri sorulduğunda; bir anne şu ana kadar çocuğuna hiç kitap almadığını belirtmiştir. Diğer anneler ise şiddet içerikli olmayan, resimli, az yazılı, çocuğun gelişimine uygun kitap aldıklarını, içeriğine, masal türünde olmasına ve çocuklarının sevmesine dikkat ettiklerini belirtmişlerdir. Bu konuda bazı annelerin ifadeleri şu şekildedir:

Kesinlikle, vurmalı kırmalı olmayan, tam tersi birazcık daha onun yaşına uygun, mesela beş yaşında bir oğlum var, ona göre daha çok basit hikâyeler, onun daha çok anlayabileceği, kelimeleri seçici olan kitaplara dikkat ediyorum. Resimli daha çok, az yazll, bunalmasin sikılmasin her gün okuyabilsin diye. Al

Bugüne kadar hiç almadım. Hep halası getirdi bize. A3

Kızımın sevmesine dikkat ediyorum. Duyduğu hikâyeler, kitaplar var; o kitaplara gidiyor. A8

Annelere çocuklarına en çok hangi tür kitaplar aldıkları sorulduğunda; anneler resimli, eğitici, öğretici, masal türünde olan, değerler eğitimine yönelik, kavram bilgisine yönelik, dilini geliştirecek kitaplar tercih ettiklerini belirtmişlerdir. Bu konuda bazı annelerin ifadeleri şöyledir:

Çok resimli, boyama aktiviteli, ögretici, eğitici, on seriydi mesela benim aldığım bir kitap. Sabah dişlerini firçalamasından, akşam yatmasına kadar olan her gün bir kitabı çok eğlenceli bir şekilde anlatmış. Mesela anne, babaya saygılı olalım, tutturmayalım, değerler eğitimi ile ilgili kitaplar. Öyle güvenmediğimiz kitabı zaten almıyoruz. A1

Masal kitapları alıyorum. Şu anda yaşından dolayı başka bir şey kaldırmaz diye düşünüyorum. A6 
Tezel, Arslan Çiftçi ve Uyanık

Küçük olduğu için masal kitapları, renkli sayfaları olan onun sevdiği türden. A8

Araştırmaya katılan annelerin çocuklarına kitap seçerken zorlanıp zorlanmadıkları ve nedenleri sorulduğunda; bir annenin kitap almadığı için görüş bildiremediği, iki annenin zorlandığ 1 çünkü etrafta kendi istedikleri kitaplara ulaşamadıkları, diğer anneler ise kitapları çocukları ile birlikte seçtikleri ve seçenekleri fazla olduğu için zorlanmadıkları bulunmuştur. $\mathrm{Bu}$ konuda bazı annelerin ifadeleri şöyledir:

Zorlanıyorum, çok zorlanıyorum, kitap bulamıyorum. O yüzden sırf Beyazıt'a gidiyorum. Ben kendi oturduğum çevremden bahsedeyim. Asla kırtasiyede onun istediği hikâye kitapları yok. 1. Sinıfa yönelik daha çok kitaplar var burada; anasınıfı için hikâye kitabı, masal kitabı yok. Buradaki tamamen yazı üzerine. Hiç resim yok, resim deseniz çok az. Bildiğim yayınevlerinden kitaplar seçerken zorlanmıyorum ama o yayınevlerini çevremde bulamiyorum. Al

Yok ikimiz birlikte seçtiğimiz için zorlanmıyorum. A2

\section{Tartışma ve Sonuç}

Bu araştırmada çocukları okul öncesi dönemde olan annelerin çocuklarına kitap okuma ve almaya yönelik görüşlerini incelemek amaçlanmıştır. Bu araştırmanın bulgularından biri, araştırmaya katılan annelerin yarısından fazlasının kendilerinin kitap okuduğunu belirtmeleridir. Kitap okuyan annelerin çoğunun ayda bir kitap ya da iki-üç ayda bir kitap okudukları bulunmuştur. Ayrıca, annelerin çoğunluğu evinde kendilerine ve eşlerine ait 0-5 arasında ya da 20 'den fazla kitapları olduğunu belirtmişlerdir. Okumanın önemi ve yararları ile ilgili annelerin sahip olduğu inançların, annelerin okul öncesi çocuklarına kitap okuma alışkanlıklarıyla (Bingham, 2007; Weigel, Martin ve Bennett, 2006) ve çocukların dil becerileri ve daha sonraki okumaya yönelik ilgileri (Skibbe, Justice, Zucker ve McGinty, 2008; Weigel, Martin ve Bennett, 2006) ile ilişkili olduğu düşünülmektedir. Bingham (2007), kitap okuma uygulamalarındaki anne-çocuk etkileşimlerinin kalitesi ile annelerin okumanın önemine yönelik inançları arasındaki ilişkiyi incelemiştir. Araştırmanın sonucuna göre, annelerin okumanın önemi ile ilgili inançlarının, annenin eğitim durumu dikkate alındığında bile, evde çocuklarıyla yaptıkları okuryazarlık etkinliklerinin kalitesini önemli ölçüde yordadığı ortaya çıkmıştır. Bu bulgular 1şığında, ebeveynlerin kendi kitap okuma alışkanlıkları ve kitap okumaya yönelik inançlarının önemli olduğu söylenebilir. Çocukların kitaplarla olan etkileşimlerinin ebeveynlerinin okuma alışkanlıklarından etkilenebildiği dikkate alınmalıdır.

$\mathrm{Bu}$ araştırmaya katılan annelerin büyük bir çoğunluğunun çocuklarına kitap okumakta olduğu araştırmanın bulgularından biridir. Ayrıca annelerin çoğunun çocuklarına iki üç günde bir ya da haftada bir kitap okudukları görülmektedir. Tezel Şahin ve Tutkun'un (2016) yaptığı araştırmada ise anne ve babaların genellikle her gün, gece yatmadan önce çocuklarına kitap okuduğu saptanmıştır. Ahmetoğlu ve Ceylan'ın (2011) ve Çakmak ve Yılmaz'ın (2009) yaptıkları araştırmada ise ailelerin büyük çoğunluğunun çocuklarına haftada bir kaç kez kitap okuduğu bulunmuştur. Kitap okuma sıklığı, çocukların dil gelişimi ile ilişkilidir (Aram ve Aviram, 2009). Ebeveynlerin okul öncesi dönem çocuklarına günde en az 2 kere kitap okumaları gerektiği düşünüldüğünde, annelerin çocuklarına kitap okuma oranının oldukça düşük olduğu söylenebilir.

Araştırmanın bir diğer bulgusu araştırmaya katılan annelerin çocuklarına çoğunlukla yaklaşık üç yaşında kitap okumaya başladıklarıdır. Bu bulgu, Kakırman Yıldız (2016) ve Ahmetoğlu ve Ceylan (2011) tarafından ortaya konan çocukların kitaplarla ilk kez çoğunlukla ikiüç yaş arası ve sonrasında tanıştığı sonucu ile benzerlik göstermektedir. Kendilerine kitap okunmaya erken yaşlardan başlanan ve sıklıkla kitap okunan çocuklar, kendilerine kitap okunmaya daha geç yaşlarda başlanan ve daha az sıklıkla kitap okunan çocuklara göre daha fazla dil becerisi göstermektedirler (DeBaryshe, 1993; Dunst, Simkus ve Hamby, 2012). Dunst, Simkus ve Hamby (2012) tarafindan yapılan çalışmada, kendilerine kitap okunmaya 12 aydan daha 
küçükken başlanan bebeklerin, kendilerine daha geç yaşta kitap okunmaya başlanan çocuklara göre daha iyi okuryazarlık ve dil becerilerine sahip oldukları bulunmuştur. Ayrıca, küçük yaşlarda kendilerine kitap okunan çocukların büyüyünce de kendilerinin kitap okuma ihtimalleri daha yüksektir; akranlarına göre daha sık kitap okuyan çocukların da okulda daha iyi sonuçlar alma ve yetişkinlikte daha iyi işlere sahip olma ihtimalleri daha yüksektir (Whitehurst ve Lonigan, 2001). $\mathrm{Bu}$ bulgular ışığında çocukları kitaplarla tanıştırma için 2-3 yaşlarının oldukça geç bir yaş aralığı olduğu söylenebilir. Amerikan Pediatri Akademisi, ailelerin çocuklarına kitap okumaya bebeklikte başlamalarını önermektedir (AAP, 2002).

Araştırmanın bir diğer bulgusu araştırmaya katılan annelerin çoğunun çevrelerinde bir halk kütüphanesi olmadığını ya da olup olmadığını bilmediğini belirtmesidir. Çevrelerinde halk kütüphanesini olanların ise büyük çoğunluğunun çocuğuna kitap almak için halk kütüphanesine gitmedikleri ortaya çıkmıştır. Yılmaz'ın (2004) yaptığı araştırmada da ebeveynlerin büyük bir çoğunluğunun çocuklarını hiç kütüphaneye götürmedikleri; Çakmak ve Yılmaz'ın (2009) çalışmasında ise ailelerin çoğunluğunun çocuklarını kitap fuarlarına götürmedikleri bulunmuştur. Çocuk Vakfı'nın yapmış olduğu araştırmaya göre, nüfusun \%40'1 hayatı boyunca hiç kütüphaneye gitmemektedir; birkaç kez gidenlerin oranı ise \%31'dir ve kütüphaneye gidenlerin yalnızca \%8'i kitap okuma amacıyla gitmektedir (Çocuk Vakfi, 2006). Kütüphaneler sağladıkları kitaplarla çocuklar için zengin kitap merkezleri olarak düşünülebilir. Çocukları ilk kez aileleri ya da öğretmenleri kütüphanelerle tanıştırabilmektedir. Özellikle küçük çocuklara yönelik olan kütüphane hizmetlerinin çocuklara kendi yaş grupları için uygun olan çok çeşitli ve farklı kitaplarla deneyim olanağı sunmaktadır. Bu nedenle, kütüphane hizmetlerinin ve etkinliklerinin duyurulması ve tanıtılmasındaki eksiklikler saptanmalı ve çözüm yolları araştırılmalıdır. Bu aşamada öğretmenlere aileleri ve çocukları yerel kütüphaneler ile ilgili bilgilendirme konusunda bazı sorumluluklar düşmektedir.

Ayrıca, araştırmada annelerin çoğunluğu çocuklarına kitap alırken, alacakları kitabı çocukları ile birlikte seçtiklerini belirtmişlerdir. Tezel Şahin ve Tutkun (2016) tarafindan yapılan çalışmada da anne babaların büyük bir çoğunluğunun kitap alınırken çocuğun fikrini aldıkları görülmüştür. Ebeveynlerin çocuklarını düzenli olarak kitapçılara, kütüphanelere, kitap fuarlarına götürmeleri önemlidir. Çocuklar buralarda çok çeşitli ve farklı türlerde kitaplara ulaşabilirler. Çocuklar çeşitli ve çok sayıda kitaba maruz kaldıkça, kitaplarla ilgili daha olumlu hissederler. Ebeveynler, çocukların sevecekleri uygun kitapları seçmeleri için onları yönlendirebilirler.

Araştırmanın bir diğer bulgusu, araştırmaya katılan annelerin evlerinde çoğunlukla çocuklarının kitaplarını koymak için ayırdıkları kitaplık veya kutu gibi özel bir bölüm olduğudur. Bu bulgu, Tezel Şahin ve Tutkun'un (2016) ve Ahmetoğlu ve Ceylan'ın (2011) çalışmasıyla benzerlik göstermektedir. Erdoğan Gür ve Demir Emre (2016) yaptıkları araştırmada evde kitaplık bulundurma durumu ile okuma tutumu arasında anlamlı bir ilişkinin olduğunu bulmuşlardır. Okudukları veya okuyacakları kitapların bir alanda çocuğun gözünün önünde olması, çocuğun ilgisini uyandirabilir. Düzenli tutulan kitaplarla ev içerisinde bir okuma merkezinin olması, çocuklara kitapların değerli olduğunu hissini verebilir.

Araştırmanın bulgularından biri de çocuklara evde en çok annelerinin kitap okuduğudur; annelerin görüşlerine göre, çocuğuna kitap okuyan babaların sayısı oldukça azdır. Araştırmanın bu bulgusu Tezel Şahin ve Tutkun'un (2016) yaptığı araştırmayla örtüşmektedir. Babaları tarafından olumlu etkileşim ile kitap okunan okul öncesi dönem çocukların, babaları kitap okuma etkinliklerinde daha az yer alan çocuklara göre, daha gelişmiş kelime dağarcığına ve iletişim becerilerine sahip oldukları ve okula daha hazır başladıkları bulunmuştur (Baker ve VernonFeagans, 2015; Forget-Dubois ve diğerleri, 2009). ABD'de ülke çapında uygulanan 4 haftalık çocuklara kitap okuma programına katılan babaların program sonunda kendilerini daha iyi ebeveyn olarak hissettikleri ve çocuklarıyla daha iyi bir ilişkiye sahip olduklarını belirttikleri bulunmuştur (FatherhoodInstitute, 2015). Bu bulgular 1şığında, anneler büyük bir role sahip olsa da, babaların da çocukların dil ve okuryazarlık gelişimi için özellikle etkili olduğunu söylenebilir. Aynı zamanda, babaların çocuklarına kitap okumalarının çocukların sadece dil gelişimleri için değil, aynı zamanda baba-çocuk ilişkisi için de önemli olduğu dikkate alınmalıdır. 
Araştırmanın diğer bulgularına göre, araştırmaya katılan annelerin çoğunluğu çocuklarının onlara kitap okumalarından hoşlandıklarını ve kendileri teklif etmediği zamanlarda çocuklarının kendilerinden kitap okumalarını bazen istediklerini belirtmişlerdir. Öğretmenlerin gözlem ve görüşlerinin alındığı bir araştırmada da çoğu öğretmenin düşüncesine göre, çocuklar kendilerine kitap okunmasından hoşlanmaktadırlar ve çocuklar okumadan zevk almaktadırlar (Ekici ve Yılmaz, 2014). Bir araştırmada, okumayı sevmeyen gençler, çocuklukta bu alışkanlığı kazanamadıklarını, büyük ölçüde evlerinde okunacak yeterli malzeme (kitap, dergi vs.) bulunmadığını ve genellikle kitaplar hakkında aile bireyleri veya arkadaşları ile sohbet etmediklerini belirtmektedirler (Arıcı, 2008). Ayrıca araştırmada annelerin büyük çoğunluğunun da çocuklarına kitap okumaktan hoşlandıkları bulunmuştur. Baker, Scher ve Mackler (1997), çocukların okumaya karşı olumlu bir eğilim sergilemeleri ve motivasyonlarının artması için ebeveynlerinin kitap okumanın eğlenceli bir etkinlik olduğuna inanmalarının ve kitap okumaya karşı olumlu bir bakışa sahip olmaları gerektiğini ortaya koymuşlardır. Ebeveynleri, okumanın keyif verici ve eğlence kaynağı olduğuna inanan çocuklar, aile geliri göz önüne alınmaksızın, okumaya karş1 daha motivedir ve okumaktan daha fazla hoşlanmaktadırlar (Baker ve Scher, 2002; Baker, Scher ve Mackler, 1997). Bu araştırma bulgusuna göre, annelerin çoğunluğu da çocuklarına kitap okumaktan hoşlanmaktadırlar. Bununla birlikte evdeki kitap sayısı, çocuklarına kitap okumaya başlama yaşı ve kitap okuma sıklığı düşünüldüğünde, bu olumlu tutumun yeteri kadar eyleme dönüşmemiş olduğu söylenebilir.

Araştırmada ayrıca, araştırmaya katılan annelerin çoğunluğunun çocuklarına kitap okuduktan sonra kitaptaki hikâye hakkında bazen sohbet ettikleri ve çocuklarından kitaptaki resimlere bakarak kendisinin bir hikâye oluşturmasını bazen istedikleri bulunmuştur. Yapılan deneysel bir araştırmanın sonucunda, anne veya babaları ile etkileşimli kitap okuma süreci yaşayan çocukların sosyal durumları anlama, sosyal sorunlara ilişkin olumlu çözüm önerme ve sosyal durumlara yönelik öyküleri olumlu biçimde sonlandırma alanlarında anlamlı düzeyde farklılık ortaya koydukları bulunmuştur (Çelebi Öncü, 2016). Dickinson ve Tabors (2001), ebeveynlerin çocuklara hem hikâye ile doğrudan ilgili olan, hem de doğrudan ilgili olmayan konuşmalar yapmalarını önermektedir. Hikâye ile doğrudan ilgili konuşma, hikâye ile ilgili soruları yanıtlamak ve resimleri etiketlemek üzerine odaklanmaktadır. Hikâye ile doğrudan ilgili olmayan konuşma ise metnin ötesine geçmekte; sözcük anlamları üzerine tartışmayı, tahminde bulunmayı ve çıkarım yapmayı ve metni kişisel deneyimler ile ilişkilendirmeyi içermektedir. Çocukların kitap okuma sırasında hikâye ile hem doğrudan hem de dolaylı olarak çeşitli konuşma firsatları bulmaları önemlidir. Küçük çocuklara kitap okuma, metnin sadece okunmasından fazlasını gerektirir. Çocukların karmaşı olayları anlamak ve olayları öyküde kullanılan dille ilişkilendirmek için desteğe ihtiyaçları vardır.

Çocukların ebeveynle birlikte kitap okuma sırasındaki tepkileri (örn., sorular, yorumlar) bu etkileşimli deneyimin önemli bir bileşenidir. En başta, çocukların okuma sırasındaki soruları ve yorumları genellikle resimler ile ilgilidir. Resimlerdeki nesneleri isimlendirirler ya da hikâyeyi dinlerken duydukları kelimeleri tekrar ederler ve yinelerler. Başlangıçta, ebeveynler, bu durumun hikâyeleri kesintiye uğratacağını düşünürler. Bununla birlikte, ebeveynler çocuklar üç yaşına geldiğinde hikâyeyi dinleyebilmesini ve ondan bir şeyler öğrenmesini beklerler (Saracho ve Spodek, 2010). Ancak, ebeveynler hikâye boyunca çocukların diyaloglarını ve sorularını kabul etmelidirler. Flood'a (1977) göre, ebeveyn-çocuk hikâye okuma etkinliği şunları içermelidir: (1) çocukları hikâyeye hazırlamaya yönelik okumadan önce sorular sorma, (2) hikâyeyi tanıdık deneyimlerle ilişkilendiren okuma sırasındaki yetişkinler ve çocuklar arasındaki sözlü etkileşimler (3) hikâyenin sonrasında değerlendirici yanıtları ortaya çıkaran sorular sorma ve (4) çocukların cevaplarını pozitif pekiştirme.

Araştırmanın bir başka bulgusuna göre, araştırmaya katılan annelerin büyük çoğunluğu çocuklarına kitap almakta; çoğunlukla da ayda bir ya da iki kez veya birkaç ayda bir kitap almaktadırlar. Ancak araştırmada aynı zamanda çocukların evde kendine ait kitapların sayısının çoğunlukla 0-5 ya da 6-10 arasında olduğu sonucu ortaya çıktı̆̆ düş̧ünüldüğünde, bu bulgunun yanıltıcı olduğu görülmektedir. Çünkü böyle bir durumda çocukların evde çok daha fazla kitaba sahip olması gerektiği düşünülmektedir. Çocukların evde sahip olduğu kitapların sayısının çok az 
olduğu görülmektedir. Çocuklar okul öncesi dönemde çok çeşitli ve farklı türlerde kitaplarla tanışmalıdırlar. Kütüphane kullanımının, özellikle maddi olanaklar yüzünden daha fazla kitaba ulaşamayan aileler açısından sağlayacağı imkânda göz önünde bulundurulabilir.

Araştırmada annelerin çocuklarına kitap alırken, kitabın en çok çocukların gelişim özelliklerine uygun olmasına, kitabın konusuna ve çocuklarının kitabı beğenmesine dikkat ettikleri bulunmuştur. Tezel Şahin ve Tutkun (2016) ise, anne babaların çocuklarına kitap alırken en çok yaşına uygun olmasına, içeriğine ve kitabın yazarına dikkat ettiklerini; en az dikkat ettikleri şeyin ise kitabın önceden okunup okunmaması, en çok satanlara göre olması ve fiyatı olduğunu bulmuşlardır. Çocuklara kitap okuma etkinlikleri için seçilen kitapların kalitesini değerlendirmek önemlidir. İyi yazılmış, etkileyici karakterlere ve olay örgüsüne sahip ve akıcı ve dışavurumsal okuma için ebeveynlere birçok firsat sunan kitaplar en iyi seçimdir (Lane ve Wright, 2007). Çocukların sevdikleri kitapların alınması ve konuları gibi özellikler de kitap okuma alışkanlıklarının sürmesi açısından önemlidir.

\section{Öneriler}

Ebeveynlere çocuklarıyla duygusal bağlarını güçlendirebilen, güvenilir ve yakın ilişkiler kurmalarına yardımcı olan kaliteli etkileşimli kitap okuma etkinlikleri yapmaları önerilebilir. Araştırmalar, ebeveynlere çocuklarına hikâye kitabı okuma etkinliğini nasıl uygulayacaklarını öğretmenin çocukların dil gelişimcileri üzerinde yararlı etkilere sahip olduğunu göstermektedir (Jordon, Snow ve Porche, 2000; Roberts, 2008). Ebeveynlerin kitap seçme yöntemlerini, kitap okuma etkinliklerini çocuklarıyla en iyi nasıl uygulayacaklarını ve çocuklarının kitap okumaya yönelik ilgilerini desteklemek için neler yapmaları gerektiğini öğrenebilecekleri eğitim programlarına ihtiyaç vardır. Okul öncesi eğitim kurumlarına, ebeveynlerin hikâye okuma becerilerini geliştirmeleri için atölye çalışmaları yapmaları ve ebeveynlerin çocuklarına düzenli ve sıklıkla hikâyeleri okumalarını teşvik etmeleri önerilebilir. Ayrıca, ebeveynler kendileri okumaya ilgi duyduklarında, çocuklarına kitap okuma ihtimalleri daha yüksektir (Bracken ve Fischel, 2008). Bu nedenle anne-babaları kendi okuryazarlık becerilerini geliştirmeleri için cesaretlendirmek de, çocuklarıyla daha fazla kitap okuma etkileşimlerinde bulunmalarına katkıda bulunabilir.

\section{Kaynaklar}

Ahmetoğlu, E. ve Ceylan, R. (2011). A study on the views of mothers of preschool children about children's books. Bulgarian Journal of Science \& Education Policy, 5(1), 5-14.

American Academy of Pediatrics (AAP) (2002). Committee on psycho social aspects of child and family health. Guidelines for health supervision. Elk Grove Village, IL: American Academy of Pediatrics.

Aram, D. ve Aviram, S. (2009). Mothers' story book reading and kindergartners' socio emotional and literacy development. Reading Psychology, 30, 175-194.

Arıc1, A. F. (2008). Okumayı niye sevmiyoruz? Üniversite öğrencileri ile mülakatlar. Mustafa Kemal Üniversitesi Sosyal Bilimler Enstitüsü Dergisi, 5(10).92-100.

Baker, C. E. ve Vernon-Feagans, L. (2015). Fathers' language input during shared book activities: Links to children's kindergarten achievement. Journal of Applied Developmental Psychology, 36(1), 53-59.

Baker, L. ve Scher, D. (2002). Beginning readers' motivation for reading in relation to parental beliefs and home reading experiences. Reading Psychology, 23(4), 239-269.

Baker, L., Scher, D. ve Mackler, K. (1997). Home and family influences on motivations for reading. Educational psychologist, 32(2), 69-82.

Beck, I. L. ve McKeown, M. G. (2001). Text talk: Capturing the benefits of read-aloud experiences for young children. The Reading Teacher, 55, 10-20.

Bingham, G. E. (2007). Maternal literacy beliefs and the quality of mother-childbook-reading interactions: Associations with children's early literacy development. Early Education and Development, 18(1), 23-49. 
Brabham, E. G. ve Lynch-Brown, C. (2002). Effects of teachers' reading-aloud styles on vocabulary acquisition and comprehension of students in early elementary grades. Journal of Educational Psychology, 94, 465-473.

Bracken, S. S. ve Fischel, J. E. (2008). Family reading behavior and early literacy skills in preschool children from low-income backgrounds. Early Education and Development, 19(1), 45-67.

Chomsky, C. (1972). Stages in language development and reading exposure. Harvard Educational Review, 42, 1-33.

Clark, C. ve Hawkins, L. (2010). Young people's reading: The importance of the home environment and family support. National Literacy Trust.

Creswell, J. W. ve Clark, V. L. P. (2015). Karma yöntem araştırmaları tasarımı ve yürütülmesi: Karma yöntem araştırmalarının doğası. Y. Dede ve S. B. Demir (Çev.). Ankara: Anı Yayıncilik.

Cunningham, A. ve Zibulsky, J. (2011). Tell me a story: Examining the benefits of share dreading. S. Neuman ve D. Dickinson (Yay. haz.). Handbook of early literacy research içinde (Say13, ss. 396-411). New York: Guilford Press.

Çakmak, T. ve Yılmaz, B. (2009). Okulöncesi dönem çocuklarının okuma alışkanlığına hazırlık durumları üzerine bir araştırma: Hacettepe Üniversitesi Beytepe Anaokulu örneği. Türk Kütüphaneciliği, 23(3), 489-509.

Çelebi Öncü, E. (2016). Etkileşimli kitap okumanın beş-altı yaş çocuklarının sosyal durumlara yaklaşımlarına etkisinin incelenmesi. Ana Dili Ĕgitimi Dergisi, 4(4), 489-503.

Çocuk Vakfı (2006). Türkiye'nin okuma alışkanlığı karnesi. http://www.cocukvakfi.org.tr /resource/pdf/raporlar/14okuma_aliskanligi_karnesi2006.pdf

De Baryshe, B. D. (1993). Joint picture-book reading correlates of early oral language skill. Journal of Child Language, 20(2), 455-461.

Dickinson, D. K. ve Tabors, P.O. (2001). Beginning literacy with language. Baltimore: Brookes.

Dunst, C. J., Simkus, A. ve Hamby, D. W. (2012). Relationship between age of onset and frequency of reading and infants' and toddlers' early language and literacy development. Center for Early Literacy Learning Review, 5(3), 1-10.

Ekici, S. ve Yılmaz, B. (2014). Ankara'daki anaokullarının okuma alışkanlığına hazırlık yeterlilikleri açısından değerlendirilmesi. Türk Kütüphaneciliği, 28(4), 547-582.

Erdoğan Gür, D. ve Demir Emre, Y. (2016). İlkokul 4.sınıf öğrencilerinin okumaya yönelik tutumlarının farklı değişkenler açısından incelenmesi. Sakarya Üniversitesi Eğitim Fakültesi Dergisi, (32), 85-96.

FatherhoodInstitute (2015). Fathers reading everyday training. Erişim adresi: $\mathrm{http} / / / \mathrm{www}$.fatherhoodinstitute.org/training-and-consultancy/fathers-reading-daytraining

Flood, J. (1977). Parental styles in reading episodes with young children. The Reading Teacher, 30, 846-867.

Forget-Dubois, N., Dionne, G., Lemelin, J., Pérusse, D., Tremblay, R. E. ve Boivin, M. (2009). Early child language mediates the relation between home environment and school readiness. Child Development, 80(3), 736-749.

Harris, J. ve Ó Duibhir, P. (2011). Effective language teaching: A synthesis of research. Dublin: National Council for Curriculum and Assessment (NCCA).

Jordon, G. E., Snow, C. E. ve Porche, M. V. (2000). Project EASE: The effect of a family literacy project on kindergarten students early literacy skills. Reading Research Quarterly, 35, 524-546.

Kakırman Yıldız, A. (2016). Okulöncesi dönem çocuklarının okuma alışkanlığı kazanmasında rol model olarak aile. Mavi Atlas, 7, 95-112.

Karasar, N. (1999). Bilimsel araştırma yöntemi: Kavramlar, ilkeler, teknikler. Ankara: Nobel Yayınevi.

Kassow, D. Z. (2006). Parent-child shared book reading quality versus quantity of reading interactions between parents and young children. Talaris Research Institute, 1(1). 1-9. 
Kennedy, E., Dunphy, E., Dwyer, B., Hayes, G., McPhillips, T., Marsh, J., O’Connor, M. ve Shiel, G. (2012).Literacy in early childhood and primary education (3-8 years). Dublin: National Council for Curriculum and Assessment. ISSN 1649-3362.

Lane, H. B. ve Wright, T. L. (2007).Maximizing the effectiveness of reading aloud. The Reading Teacher, 60(7), 668-675.

Majzub, R. ve Abu, S. (2010). The practice of reading books and reading to children in the context of peer-groups in the preschool classroom. Procedia Social and Behavioral Sciences, 9, 753-757.

Morrow, L. M. ve Gambrell, L.B. (2002).Literature-based instruction in the early years. S. B. Neuman ve D. K. Dickinson (Yay. haz.). Handbook of early literacy research içinde (ss. 348-360). New York: Guilford.

Phillips, L. M., Norris, S. P. ve Anderson, J. (2008). Unlocking the door: Is parents' reading to children the key to early literacy development? Canadian Psychology, 49(2), 82-88.

Roberts, T. A. (2008). Home story book reading in primary or second language with preschool children: Evidence of equal effectiveness for second-language vocabulary acquisition. Reading Research Quarterly, 43(2), 103-130.

Saracho, O. N. ve Spodek, B. (2010). Parents and children engaging in story book reading. Early Child Development and Care, 180(10), 1379-1389.

Sawyer, W. E (2004).Growing up with literature (4.ed). New York: Thomson Delmar Learning.

Sharif, I., Ozuah, P.O., Dinkevich, E. I. ve Mulvihill, M. (2003).Impact of a brief literacy intervention on urban preschoolers. Early Childhood Education Journal, 30, 177-180.

Skibbe, L. E., Justice, L. M., Zucker, T. A. ve McGinty, A. S. (2008). Relations among maternal literacy beliefs, home literacy practices, and the emergent literacy skills of preschoolers with specific language impairment. Early Education and Development, 19(1), 68-88.

Strommen, L. T. ve Mates, B. F. (2004). Learning to love reading: Interviews with older children and teens. Journal of Adolescent \& Adult Literacy, 48(3), 188-200.

Tezel Şahin, F. ve Tutkun, C. (2016). Okulöncesi dönemde anne, baba, çocuk ve kitap. Kastamonu Ĕ̈itim Dergisi, 24(5). 2373-2390.

Trivette, C. M., Simkus, A., Dunst, C. J. ve Hamby, D.W. (2012). Repeated book reading and preschoolers' early literacy development. Center for Early Literacy Learning, 5(5), 1-13.

Weigel, D. J., Martin, S. S. ve Bennett, K. K. (2006). Contributions of the home literacy environment to preschool-aged children's emerging literacy and language skills. Early Child Development and Care, 176 (3-4), 357-378.

Whitehurst, G. J. ve Lonigan, C.J. (2001). Emergent literacy: Development from pre-readers to readers. S. B. Neuman ve D. K. Dickensen (Yay. haz.). Handbook of early literacy research içinde (ss. 11-291). New York, NY: Guilford Press.

Yıldırım, A. ve Şimsek, H. (2006). Sosyal bilimlerde nitel araştırma yöntemleri (6.Baskı). Ankara: Seçkin Yayınevi.

Yılmaz, B. (2004). Öğrencilerin okuma ve kütüphane kullanma alışkanlıklarında ebeveynlerin duyarlılı̆̆. Bilgi Dünyası 5(2), 115-136.

\section{Extended Abstract}

\section{Introduction}

Reading books to children is considered one of the most important aspects of early literacy development. The benefits of reading to children have been proven by research (Beck \& McKeown, 2001; Brabham \& Lynch-Brown, 2002; Sharif, Ozuah, Dinkevich \& Mulvihill, 2003). When the relevant literature is examined, adults are defined as guides in the reading process. When children are provided with appropriate settings, children can acquire imagination, creativity and critical thinking, which are important elements in reading (Majzub \& Abu, 2010). Positive parental behavior (such as being supportive) enables children to focus and excite during story interaction (Kassow, 2006). The aim of this research is to examine in depth the views of mothers about reading and buying books for their preschool children. 


\section{Method}

This research was conducted through a mixed method. First, survey model from quantitative research methods was used. Secondly, case study from qualitative research methods was used. Qualitative data were obtained through question form from 292 mothers of preschool children based on their self-statement. In the question form developed by the researchers, there are 24 questions related to mothers' reading and buying books for their children. Quantitative data were obtained from face-to-face interviews with 9 mothers. Interviews lasted about 20-25 minutes. In the interview form developed by the researchers, there are 8 open-ended questions. The quantitative data obtained were evaluated by calculating frequency and percentage. Qualitative data were subjected to descriptive analysis. Obtained data were analyzed by two researchers. Miles and Huberman (1994) formula (Reliability = Consensus / Consensus + Dissidence) was applied to the two researcher's encodings. The concordance between the researchers was calculated as $94 \% .70 \%$ or above scores are accepted as sufficient for reliability claims.

\section{Results}

Results show that most of the mothers read a book in a month; have between 0 and 5 books belonging to themselves and their spouses at home; read book to their children every two or three days; have between 0 and 5 books belonging to their children at home; began to read books to their children when their children are about three years old; do not have a public library in their neighborhood; choose books with their children together when buying books. In addition, most of the mothers who participated in the study have a special area in their home to set aside their children's books; read to their children mostly themselves at home; like to read books to their children and their children also like being read to themselves; sometimes talk with their children about the story in the book after reading; sometimes want from their children to make up a story themselves by looking at the pictures in the book; buy books for their children once or twice a month. It was also found that when buying books for their children, mothers pay attention mostly to whether the book is suitable for children's developmental characteristics, topic of the book and whether their children like the book.

\section{Discussion}

Parents' own reading habits and beliefs about reading are important. The mothers' beliefs about the importance and benefits of reading has been found to be related to their habits of reading books to their preschool children (Bingham, 2007; Weigel, Martin and Bennett, 2006), and children's language skills and their interest in later reading (Skibbe, Justice, Zucker \& McGinty 2008; Weigel, Martin \& Bennett, 2006). Two-three years is quite late for children to get acquainted with books. Children who are read books an early age develop more language skills than children who are read at a later age (DeBaryshe, 1993; Dunst, Simkus \& Hamby, 2012). The American Academy of Pediatrics recommends that families should begin reading to their children during infancy (AAP, 2002).It is important to assess the quality of selected books for children's reading activities. Books that are well-written, with impressive characters and plot, and offer parents many opportunities for fluent and expressive reading are the best choice (Lane \& Wright, 2007).

As a result, it can be recommended that parents should engage in quality interactive book reading activities that can strengthen their emotional ties with their children and help them build reliable and close relationships. Research has shown that teaching parents how to apply story reading to their children has positive effects on children's language development (Jordon, Snow \& Porche, 2000; Roberts, 2008).In light of all findings, it can be said that there is a need for education programs that parents can learn about book selection methods for their children, how best to use book reading activities with their children, and what they need to do to support their children's interest in book reading. Research shows that teaching parents how to apply storybook reading activity to their children has beneficial effects on children's language development (Jordon, Snow \& Porche, 2000; Roberts, 2008). It can be suggested for preschool institutions to do workshops for parents to improve their story-reading skills, and to encourage parents to read their children regularly and frequently. In addition, because parents are more likely to read books 
to their children when they are interested in reading (Bracken \& Fischel, 2008), encouraging parents to develop their own literacy skills can also benefit children's language and literacy development. 